\title{
Civil Society: Overlapping Frames
}

\author{
Bronwen Dalton \\ University of Technology, Sydney
}

\begin{abstract}
The social sciences are bedeviled by terminological promiscuity. Terms and phrases are used at one time in a certain context and later borrowed and applied in different circumstances to somewhat different phenomena. Sometimes different groups of actors or researchers simultaneously use the same term with somewhat different meanings. Such is the use of the term civil society. In this 5th Anniversary of the Cosmopolitan Civil Societies: An Interdisciplinary Journal, it is timely to trace the evolution of the idea of civil society to its multiple guises in the present. The paper reviews the term's 18th and 19th century roots, its recent resurrection and the opposing views of civil society, including views that question its applicability to non-western settings. It then discusses prospects for developing agreed approaches to the study of civil society. To guide our thinking the paper presents a brief overview of different approaches to defining civil society taken by some of the major so-called centres for civil society in Australia and internationally. The paper concludes by reflecting on these definitional challenges as it has played out at one particular cross faculty research centre, the University of Technology, Sydney’s Cosmopolitan Civil Societies Research Centre.
\end{abstract}

\section{Civil society: Overlapping Frames}

The social sciences are bedeviled by terminological promiscuity. Terms and phrases are used at one time in a certain context and later borrowed and applied in different circumstances to somewhat different phenomena. Sometimes different groups of actors or researchers simultaneously use the same term with somewhat different meanings. Such is the use of the term civil society. In this 6th Anniversary year of the Cosmopolitan Civil Societies: An Interdisciplinary Journal it is timely to trace the evolution of the idea of civil society to its multiple guises in the present and then to consider its prospects in the near future. 
An important component of most conceptions of civil society is to connote a particular set of organisations that are neither government nor operated for a profit. Again, these are described in a variety of ways: social movement organisations, NGOs, nonprofit organisations, voluntary organisations, social economy organisations and so on. Some group them under the descriptor of 'third sector'. The paper will outline the main ways in which civil society have been conceptualised and studied. The paper then examines how this rich yet tangled conceptual history has led to two major challenges confronting those wishing to operationalise the concept of civil society. First, contemporary scholars have demonstrated a tendency to preference one part of civil society and focus on a particular setting and then equate the phenomena that they observe to civil society itself. Second, various difficulties arise when transferring the concept of civil society to non-western settings. Arguably, both problems stem from the lack of a precise definition. One can be pessimistic or optimistic about this state of affairs for those engaged in the field. Perhaps seeking agreement on a shared definition is unnecessary and misses the point of the field which is to build and expand our knowledge of social change? Or perhaps collaboration among the members of the different centres for civil society across the world may lead to the excavation of some common ground?

The discussion below first looks at approaches to defining civil society; then discusses the term's new found popularity; presents a (deliberately polemic) outline of opposing views of civil society; examines how the term's relevance to non-western settings has been questioned and concludes by looking at current approaches taken by those in the field.

\section{Popular term but what does it mean?}

'Civil society' is a hot topic. Today there is almost no field devoted to the study of social or political change, be it sociology, political science, history or even economics, that omits mention of the importance of civil society. Jean and John L. Comaroff describe the concept as the 'Big Idea of the Millennial Moment' (Comaroff and Comaroff 2001, p. 40) while UN Secretary General Kofi Annan labeled civil society as ‘the new superpower’ (UN 2003). Using the media search tool Factiva ${ }^{1}$,Figure 1 shows how the frequency of the appearance of the term in the media has risen exponentially over recent decades(although note this sample is biased as its searched only media sources published in English).

\footnotetext{
${ }^{1}$ Factiva aggregates the content of over 36,000 sources (such as newspapers, journals, magazines, television and radio transcripts etc.) from almost 200 countries in 28 languages.
} 
Figure 1: Frequency of term 'civil society' 2001-2014

(NB in Global Media English language sources only ( $\mathrm{N}=585418$ documents))

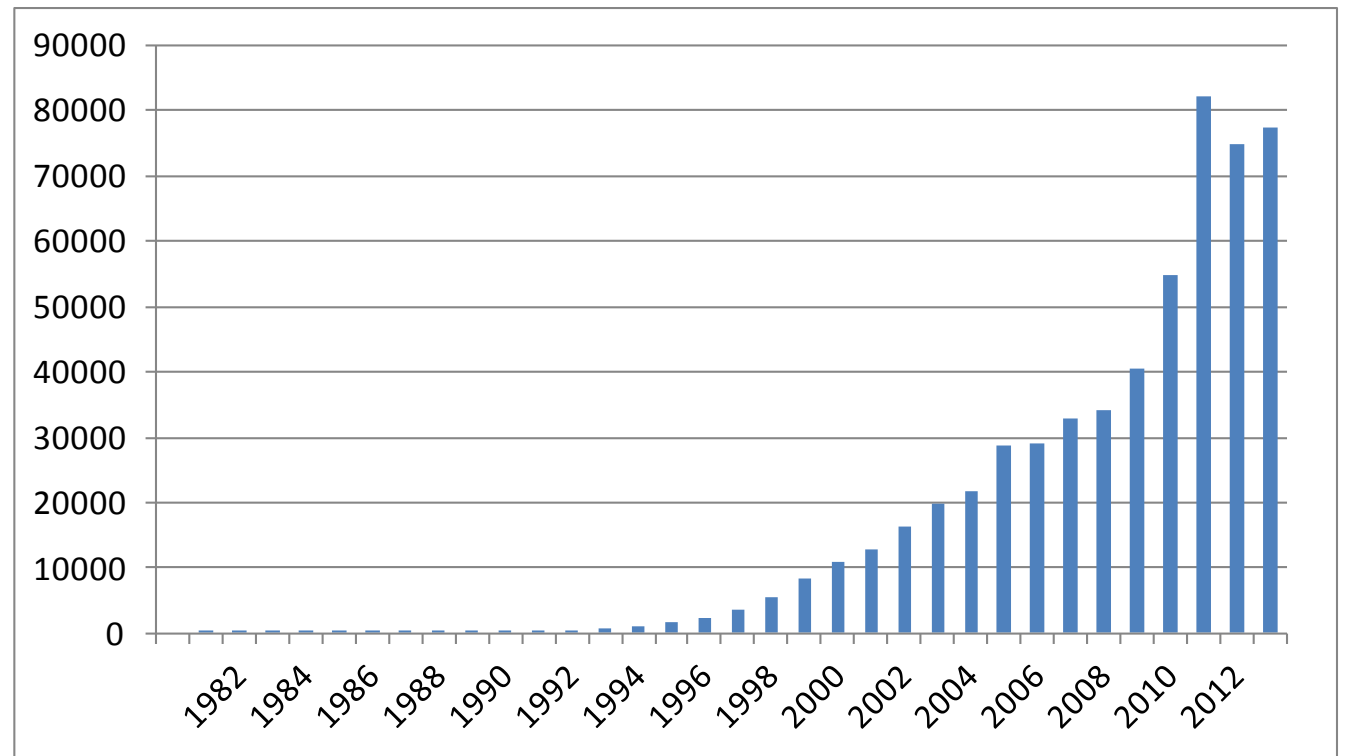

Source: (C) 2014 Factiva, Inc.

Despite such ubiquity in the academic and wider discourse, consensus on the meaning of civil society remains elusive. According to Benjamin Barber (1996) 'The more the term civil society has been used in the recent years, the less it has been understood.' What are the possible reasons for this prolonged and fierce debate and what are the consequences for the study of civil society? Has the debate generated heat or light? It may be that the consequent confusion has hindered the laying down of a conceptual foundation strong enough to support future research. Confusion may also mean that the concept has become victim to neglect or attack. Alternatively we can view the current unresolved state of play as reassuring - in that this heated debate has assumed many of the characteristic of civil society itself - open, discursive, contentious, dynamic, or as Michael Walzer argues,

Civil society is an experiment or a long series of experiments, in the sense that everything about it is tentative and subject to revision, but no one is in charge of the experiments (2002, p.44). 
After all, as Nietzsche has pointed out, concepts with histories elude definition (From Nietzsche's The Genealogy of Morals, Essay 2, Section 13, tr. Kaufmann and Hollingdale 1968).

\section{Opposing views of civil society ${ }^{2}$}

The term civil society became in vogue in the 18th and 19th centuries in context of the rapid development of capitalism and the spread of liberal ideas in Britain and Europe, a time when those who controlled capitalist production, a rising bourgeoisie, sought access to political power and freedom as well as being able to exercise their new found economic freedoms Pitts 2009). These c18th and c19th uses of the term civil society throw some light on current debates on the topic.

The 18th and 19th centuries were a period when disciplines, first political theory and philosophy and later sociology, developed ways of theorising the relationships between society, state, economy and political society (Kuper and Kuper 1985). Although some of these theories purported to provide explanations, they were also deeply normative in the value commitments and ethical and political orientations (more about the normative dimensions of theories of civil society below).

First, it is useful to sketch out the dominant conceptions of civil society developed first in the work of political philosophers and theorists, namely, Georg Wilhelm Friedrich Hegel, John Locke and Thomas Hobbes. Then the legacy of their contribution to the emergent discipline of sociology in the 19th century and its trajectory is mapped out in the work initially of de Tocqueville and later in the work of $20^{\text {th }}$ century sociologists such as Gabriel Almond and SidneyVerba and later still Robert Putnam and Edward Shils. In discussing modern conceptualisations of civil society, reference is also made to the work of political scientists such as Helmut Anheier and in particular democratisation theorists such as Seymour Martin Lipset, Larry Diamond, Philippe Schmitter, Guillermo O’Donnell and Lucian Pye (Almond \& Verba 1989; Putnam1993, 1995; Shils1997; Anheier2004; Lipset1956, 1967;

Diamond1994;Schmitter1995;O’Donnell \& Schmitter 1986; Pye, 1999).

\footnotetext{
${ }^{2}$ Parts of this section were developed in the unpublished conference paper: Bronwen Dalton and Virginia Watson, 2007 'Civil Society, Third Sector: Overlapping Frames' presented at the University of Technology, Sydney, Conference on Cosmopolitan Civil Societies, 4-5 October, 2007 Sydney.
} 
One conception of civil society that became very influential is that which derives from the work of the German philosopher G.W.F. Hegel (1770 -1831) and which we see developed more fully in republican political thought (or more precisely participatory republicanism - see Morris 2006). This 'Hegelian’ conception of civil society involves tying the term to a specific set of institutions or organisations that are held to 'mediate' between public and private life (Kelsay 2002, Hegel tr Wood 1991). Examples of these organisations and institutions include churches, labour unions, political parties, most social movements, and NGOs. In this Hegelian and more recently republican tradition in political thought, organisations like these are held to be critical for the development of the type of people who can participate as full citizens in the political life of a modern state. As John Kelsay explains, "they mediate in the sense that taking part in them helps people develop loyalties beyond kinship” (2002, p. 3). In other words, the importance of civil society in these terms is that it represents a crucial stage in the development of a people who can deal with those who are different from themselves. Kelsay argues that “this quality is held to be crucial 'practice' in anticipation of the more extensive experience of difference characteristic of the modern state and society” (2002, p. 3).

Another influential conception of civil society is that which comes from the English political philosopher, John Locke (1632-1704) and which has gone on to inform the work of liberal Anglo-American writers in particular. Locke argued that the consolidation of political power can be turned into autocracy, if it is not brought under reliable restrictions (Kaviraj 2001, p. 291) and saw civil society as largely akin to a certain kind of political or governmental regime, namely, constitutional democracy. The mediating organisations such as unions and churches feature in this conception of civil society and are seen as crucial counterweight to the power of government. Strong mediating organisations act to balance governmental power and also enable people to pursue their collective interests (interests that in non-civil societies give rise to violence). Here the argument is: give people the freedom and opportunity to participate in a wide set of forms of social life and thereby to learn to tolerate different points of view and ways of life. In this sense, strong institutions help keep society civil. This will have the effect of limiting the tendencies of government towards authoritarianism and disenfranchised citizens toward communal strife - this is the Lockean tradition (Locke 1965).

Lastly, a third influential conception of civil society is that which derives from the work of the political philosopher Thomas Hobbes (1588-1679). For Hobbes, self-interests motivate human beings (Graham 1997:23). With this worldview, society - or more precisely civil 
society institutions - do not make the state civil, but rather, it is the state which civilises society. 'Society' and individuals in this Hobbesian tradition are too driven by their passions (and not enough by their interests - their rational, self-interest). And because of these 'passions' - religious, ethnic, national, cultural - it is fundamentally impossible for human beings to achieve any measure of self-government. Therefore, to civilise society, the state needs to exercise absolute sovereign authority. The absolutism and authoritarianism of Leviathan in this tradition is seen as essential to the necessary civilisation of society (Ewin1991, Hampton 1986).

These conceptions of civil society, as they derive from the political philosophy and political theory developed in the 18 th and $19^{\text {th }}$ centuries, have gone on to inform the development of thinking in the discipline of sociology on the topic. In particular, one of the first sociologists to take seriously the idea of 'civil society' was Alexis de Tocqueville (1805 -1859).In his Democracy in America (which appeared in two volumes: 1835 and 1840), de Tocqueville developed his concept of civil society from a vantage point in which he was able to draw on both Hegeleian and liberal/Lockean models. When de Tocqueville looked at society in the 19th century in the United States of America he saw hundreds of voluntary associations and community organisations doing the work that kept the government accountable, democracy alive and its citizenry active and politically engaged. More recently, we have seen the legacy of de Tocqueville in the work of many 20th century sociologists including Gabriel Almond and Sidney Verba and later Robert Putnam and Edward Shils (Almond \&Verba 1989; Putnam1993, 1995; Shils1997).

\section{Contemporary normative definitions of Civil Society: the CWA versus the Solidarity versions of civil society}

In the latter half of the $20^{\text {th }}$ century, civil society is increasing proffered as a kind of panacea to the many ills of the modern world. Scholars who see civil society as having such cure all powers generally fall into one of two groups: One group drawing on both Hegelian and Lockean traditions argue that civil society has a civilising influence, that it encourages trust and reciprocitythat in turn supports citizen engagement and by extension the functioningof democratic states. The second group, drawing more emphatically on the Lockean tradition and a commitment to constitutional government views civil society principally in terms of its role as a counterweight to authoritarian states and thus a driver of regime change. Foley and Edwards (1996) describe these two modern versions as Civil society I and Civil society II. 
We can somewhat irreverently refer to Civil Society I asthe Country Women’s Association (CWA) version and Civil Society II as the Solidarity (ie in Poland) version. The division can largely be attributed to contemporary scholars' tendency to preference one part of the sector and focus on a particular political setting and then equate the phenomena that they observe to civil society itself.

It should be noted that below I present idealised and extreme 'versions' of civil society by comparing the 'good' versus the 'bad /ugly side' of civil society. It is a deliberate construction of a [false] polemic. It is important to note that historically few organisations represent the ideal democratic supporter of society and/or act as appropriate counterweights to the state. Similarly, it is true that there are historically few organisations that represent the ideal 'ugly version' of civil society. The vast majority of civil society organisations muddle along somewhere in the middle, with some commitment to values of social justice, democratic decision making, and social change, but falling short of actually fulfilling these ideals consistently. This is, of course, human and this construction of ideal types is designed to be purposely provocative to highlight how civil society research has generated debate.

\section{Civil society as supporter of democratic state: the CWA version}

Robert Putnam (1993) has argued that organisations in civil society are vital for democracy. This is because they build social capital, trust and shared values, which are transferred into the political sphere and help to hold society together, facilitating an understanding of the interconnectedness of society and interests within it. This approach focuses on how the governance and other internal political activities of many civil society organisations facilitates better awareness and a more informed citizenry, who make better voting choices, participate in politics, and hold government more accountable as a result. The norms and practices of these organisations have often been considered micro-constitutions because they accustom participants to the formalities of democratic decision making (Putnam 1994).

Some theorists have taken this approach a step further with scholars such as Cheshire Calhoun (2000), Edward Shils (1997) and most recently Helmut Anheier (2007) advocating to bring civility, ie courtesy, back in to the civil society debate. Anheier notes that if we 'neglect of the notion of civility, both conceptually and empirically' within civil society discourse we risk a 'potential slow-down in generating new knowledge and understanding of global civil society' (2007, p. 1). Civility has connotations of good manners or politeness but 
also goes deeper to link with classically liberal ideas of civility as a concern for the interests of 'private' authority and order, such as the family, religious institutions, clubs and community organisations. But could this lead to us missing key civil society actors?

\section{Civil society as counterweight to state: The Solidarity version}

The literature on links between civil society and democracy has its roots in early liberal writings like those of de Tocqueville. However the literature on these links was developed in significant ways by 20th century theorists like Gabriel Almond and Sidney Verba, who identified the role of civil society in a democratic order as vital. Seymour Martin Lipset observed in Union Democracy (1956) that voluntary groups help mobilise diversity in the political arena and thereby make it more difficult for movements such as Communism and Fascism to dominate a society. Lipset emphasises how they are a training ground for politics, a source of new ideas, and a significant method of communication (p. 16, pp. 82-86).

However, the term got a new lease of life during the democratisation period, described by Samuel Huntington as the third wave, particularly the regime change sweeping Eastern Europe and Latin America in 1970s and 80s. During this time the credibility of the transformative potential of civil societywas reinforced by its perceived political role in the overthrow of the former communist regimes. Scholars studying these political transitions argued that the emergence and 'activation' of civil society is a major weapon against despotism and the key driver of democratisation. This resurrected civil society provided the critical basis for the articulation and aggregation of interests and of exerting pressure on the state to liberalise the political system and now is the means to deepen political reforms in the post-socialist societies (O’Donnell and Schmitter 1986; Pye 1999). Larry Diamond writes, 'increasingly, scholars are recognising the symbiotic nature of the relationship between state and civil society, in the process of democratic consolidation and more generally. By enhancing the accountability, responsiveness, inclusiveness, and hence legitimacy of the regime, a vigorous, pluralistic civil society strengthens a democratic state and moves it toward consolidation' (Diamond 1997, p. 34).

What both strands share however is their normative orientation as it presupposes a certain level of civic culture and civic consciousness. Both groups of scholars view civil society as generally something desirable to have, for both promoting democracy and achieving a good 
society, and as an important barometer of modernity and social progress (Hall 1995; Keane 1998).

\section{Limitations and problems with current approaches}

But civil society - whether you understand it in Hegelian or Lockean terms - ain't always pretty, as the saying goes, and can make things worse. Also it can often make no difference at all. Finally, civil society has had a great deal - probably too much - asked of it.

First, the ugly side of civil society

Not all associative experiences cultivate the reciprocity, trust, and recognition Putnam envisages (Putnam 1993, chap 6). Civil society can be flavoured by exclusivity, inequality and worse: violence, favouritism, graft, and corruption. NGOs are commonly regarded as open affairs, as groups like (some) trade unions or humanitarian organisations such as the Red Cross. But civil society also includes exclusive, secretive or ritualistic groups that can generate bonding rather than bridging social capital, that is, the type of social capital that strengthens the links between people with the same background and that have similar objectives to create closed communities (Portes 1998). As Charles Hauss (2003) argues 'bonding social capital can serve to reinforce our preexisting beliefs including our prejudices'. Associations such as the Orange Order, Freemasonry, and Opus Dei all flourished but within tightly controlled memberships. In a sense they were the original international NGOs. More recently, we have seen Nazism and Fascism emerging from secretive organisations, later in the violence generated by civil society groups in groups in parts of the Middle East and Africa. Even Putnam’s seemingly innocuous Society of Elks has been described as a stronghold of sexist and racist views of 1950s America (Foley and Edwards 1996).

Before I proceed I will reiterate my point above, and I have selected some cases to build this polemic. Recent debate and empirical research on the subject has questioned whether bonding social capital, for example, has any associated risk of exclusivity. Instead it has identified how both bonding and bridging are essential in any healthy organisation/network. Bonding is essential to establish a sense of belonging and commitment and mutual support, but bridging is essential to connect with new information and other networks. For example the findings of studies in Australia and Ireland suggest that a model for a high social capital society might be a chain of well-bonded groups each with strong links to some other groups (Leonard \&Onyx 2003; Onyx \& Edwards 2010; Leonard 2004). 
Second, civil society that can make things worse

In particular, the democratising potential of civil society associations (assumed by those classical models of civil society) can be undermined by a paucity of democratic process within associations themselves. Here, inequalities of membership tend to mirror other inequalities. Indeed, it is likely associations now multiply the influence of those who already have resources (Verba et al. 1995, chap 16; Warren 2001, p. 19). Lipset (1967) argues that in Latin America high-status social clubs have sustained the governing class, and major agricultural organisations are the preserve of the elite (1967, p. 9). In a similar vein, Foley and Edwards (1996) have questioned how democratic civil society actually is, noting that some civil society actors in the US have now obtained a remarkable amount of political power without anyone directly electing or appointing them; on this basis they warn of 'warring factions' and 'rent-seeking special interests' (1996, p. 39). As for those democratisation theorists that focus on civil society as a counterweight to the state, Foley and Edwards astutely observe that 'There is no reason in principle why the 'counterweight' of civil society should not become a burden to a democratic as well as an authoritarian state’ (1996, p. 40).

\section{Third, civil society can often make no difference}

In this regard it is worth considering those large, highly bureaucratic organisations that are unlikely to promote much membership engagement at all - Putnam's so-called cheque-book organisations - where the only connection between ordinary members and those that run the organisation is made when they pay their annual dues; in Australia the NRMA, and in the US groups like the Sierra Club are perhaps examples. These large organisations are the kind that Theda Skopol (2003) fears are signaling the death of grassroots organising and, in turn, the diminishing of democracy in America.

\section{Finally, civil society has too much asked of it}

Economic factors and political culture are also politically important for establishing democracy. Sometimes they are the dominant factors at play. Moreover - and this relates to the point above about making no difference - without legal structures and political systems, associations are much less likely to successfully cultivate the 'habits of the heart' and for this to translate into strengthening civic engagement and democratic consolidation. An overly civil society-centric view fails to acknowledge how the interactions of various parts of 
society and polity are also a key source of civil society's effects (see Whitehead 1997). Activists in weak or failed states face enormous challenges promoting democratic other kind of civic minded values in the absence of any rules of the game (Whitehead 1997). The current situation in places such as Syria and the Sudan are cases in point.

\section{Questioning from the South}

The popularity of the civil society concept is not restricted to countries with a European historical background. The term is often used in Latin America, Africa and East Asia. Many Latin American and African countries can claim to have a tradition of civil society due to the legacy of European colonialism. But even in East Asia, which has had a very different history and set of traditions from Europe or Latin America, the language of civil society has great appeal and is used as frequently to talk about the recent transition to democracy as in other continents. While not representative of the scholarly literature, using Factiva, media coverage can serve as a proxy measure to demonstrate the breadth of interest in civil society. Figure 2 below shows the frequency of the term 'civil society' in English language media that also includes mentions of specific countries from January 11981 to 31 Dec 2013.

Figure 2 below shows the frequency of the term 'civil society' in English language media that also includes mentions of specific countries from January 11981 to 31 Dec 2013. It is important to note that this search was of media that appeared in English only so is biased in favour of the western media. However, in terms of specific media outlets outside of the newswires and 'BBC - All sources'(n. 37,713) the largest numbers of mentions of 'civil society' appeared in 'Times of India - All sources' at 11,480, The Hindu (India) at 7,072 and The Nation (Pakistan) at 4,712. Although some of these outlets may republish syndicated news more than other media outlets it nevertheless suggests that interest in civil society is strong outside of the western world.

It should also be noted that only the total number of mentions 1981-2013 appear but the coappearance of civil society and specific countries or regions will be relatively high during certain periods, for example 7,420 of the 10,470 mentions of civil society and the Middle East occurred between 2011 and 2013 in media coverage relating the 'Arab Spring'. The application of civil society to the Arab Spring is a case of stretching civil society to fit an array of complex and context specific circumstances. Further, it raises questions about whether the term 'fits' outside of the west. 
Figure 2: Frequency of 'civil society' in English language media by country 1981-2013

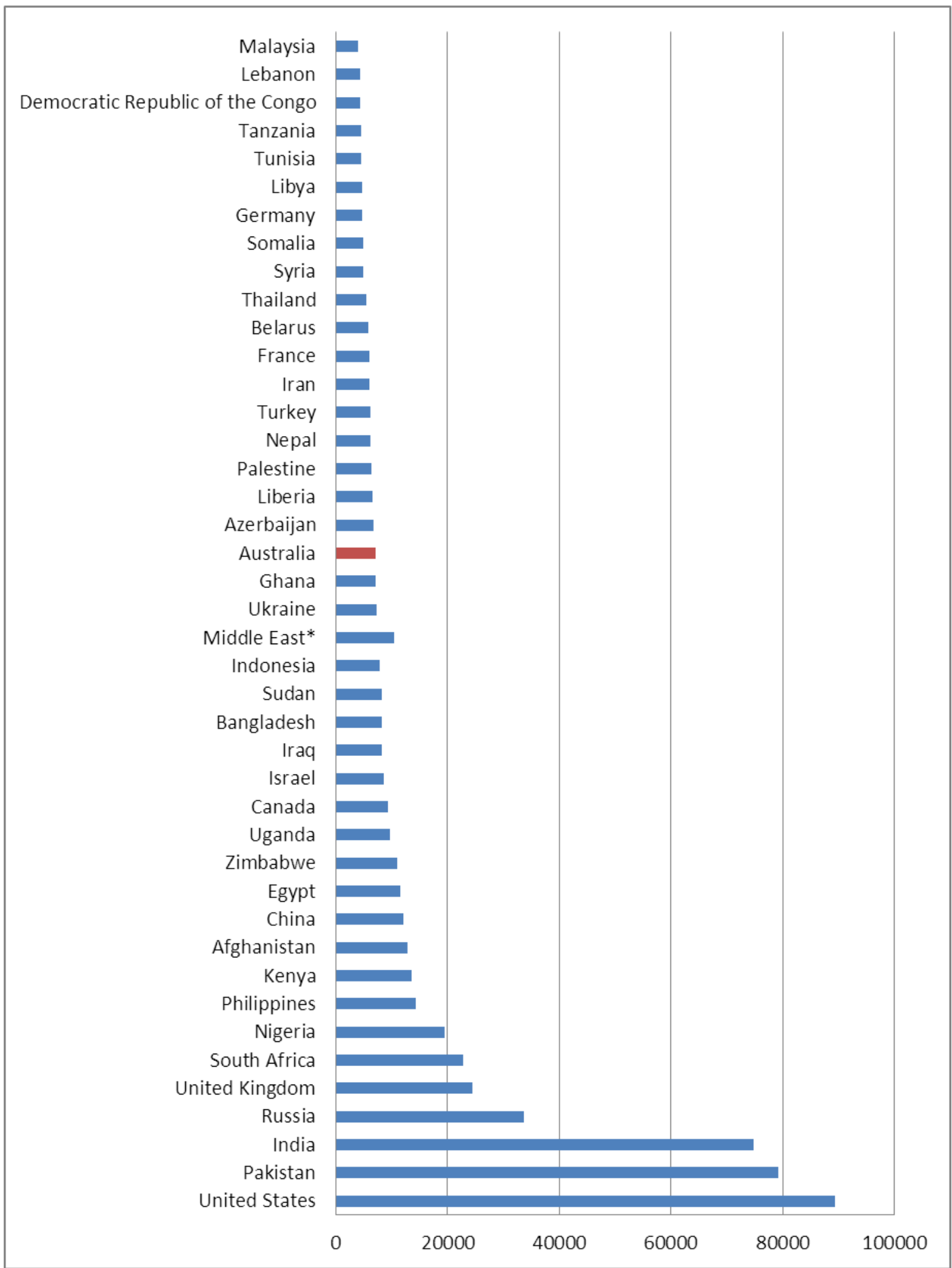

Source: (C) 2014 Factiva, Inc 


\section{Failure to account for different civil society traditions}

The democratising potential of civil society in non-western settings has been widely celebrated (see discussion by Lewis (2001) on Keane’s (1998) view of role of civil society in Japan and Harbeson's (1994) on civil society in Africa). For many in the west, and in particular in the eyes of western governments, civil society is most virtuous when the focus of its advocacy lies elsewhere, such as in the developing world. The actions of civil society seem to diminish in virtue - in the minds of politicians - when turned on the regimes in which they are situated. Then, civil society is seen more as an irritant (Dalton and Butcher 2014).

Accompanying the adoption of the term have been debates regarding emerging civil societies notably in Africa (Ebenezer Obadare, Nira Wickramasinghe, etc) and Asia (Neera Chandhoke, Carter J. Eckert, Bruce Cummings) and non-western settings in general (Munck 2006) that raise questions about the term's applicability and usefulness, with scholars calling for a re-imaging at least of the concept. These authors argue that historical circumstances, intellectual contexts and institutional arrangements in the West have influenced how the civil society has been interpreted. And that the term civil society is so deeply rooted in the specific experiences of a few selected western countries that it has significant limitations in explaining the realities of non-western societies. It has also been argued that civil society is biased towards the global north. Partha Chatterjee has argued that, in most of the world, 'Civil society as an ideal continues to energise an interventionist political project, but as an actually existing form it is demographically limited.' (Chatterjee 2006, p. 39). For Jai Sen, civil society is a neo-colonial project driven by global elites in their own interests (Sen 2010).

\section{How separate from the state?}

Related to the point above, another major difficulty is the notion that civil associations must be 'autonomous.' To a certain extent, this is because the notion of civil society promises the extension of civil as opposed to state-driven forms of association as a good. And that civil society itself refers to a realm separate from - often contrasting with or indeed counterbalancing - state power. Ernest Gellner said, 'Civil society...is first of all that part of society which is not the state. It is a residue' (Gellner 1990, p.307). However, this posits an easy separation between state and society, one which in practice hardly exists. In particular, 
the state has dominated civil society in much of the developing world, and thus civil society has not been as much separated from the state as in the Western democracies (Cotton 1992). For example in the case of Japan, Schwartz argues that the Japanese state plays an active role in targeting and monitoring welfare corporations that could well operate as part of civil society, but which instead ended up serving as non-profit 'subcontractors' for the state (Schwartz 2003, p. 13). (Here, incidentally, it is interesting to note that the clubs and societies in Northern Italy described by Putnam in his seminal Making Democracy Work: Civic Traditions in Modern Italy (1993) were backed by political parties).

Bruce Cummings (2002) decries the uncritical application of civil society in the study of East Asia as an example of hegemony of Western liberalism yet (somewhat contrarily) also criticises many western scholars (he singles out Putnam) for failing to account for the existence (at least in any significant way) of civil society existing there at all. He argues that this is because many western scholars interpret nonwestern contexts as entirely unsuitable settings for civil society (2003, p. 16). Calhoun argues that 'the cosmopolitan ideas of global civil society can sound uncomfortably like those of the civilizing mission behind colonialism' (Calhoun 2003, p. 93). Munck (2006) also discusses a failure to take account of other civil society traditions and the application of civil society as being part of the Western modernisation project.

Neera Chandhoke (2003) a political scientist from India, argues that application of civil society to nonwestern context is not only problematic but has made matters worse in terms of political and economic development. Chandhoke argues the unquestioning faith in civil society as the driver of democracy and economy growth has stimulated the expansion in developing countries of a 'fake' civil society sponsored by government as a way for them to gain access to development aid or to provide the illusion of popular support for Northern political projects. Related to this (and the points about imperialism above) Chandhoke (2002) argues these fake NGOs become agents of westernisation. Nira Wickramasinghe describes the 'instrumentalization of this neo-Tocquevillian conception of civil society... where civil society is becoming a means to an end - democratization, economic growth or sustainable development - rather than an end in itself' (2005, p. 458).

These problems of course all relate back to the problem of definition - or more precisely the lack thereof. 


\section{How is this definitional no-mans-land resolved by those in the field?}

Regardless of, or because of, the uncertainty it appears that being vague or avoiding defining civil society is a popular route. One indication is how a selection of entities that describe themselves as 'Centre for Civil Society' or close variations thereof. After conducting a search through Google for the terms 'civil society' and 'centre', examining the membership of the US based Nonprofit Academic Centers Council (NACC), a group dedicated to the promotion and networking of centres that provide research and education relating to the nonprofit sector (NACC 2014) the following 15 centres were identified. Most are affiliated with a university. Table 1 shows how the centres, both those aligned with Universities and those with Community, for-profit or even government affiliations, deal with the thorny issue of how to define civil society. ${ }^{3}$ (Note that the centres are listed in no particular order).

\section{Table 3: Definitions of civil society included on websites/key literature of civil society centres}

\begin{tabular}{|c|c|c|}
\hline NAME OF CENTRE & $\begin{array}{l}\text { AFFILIATION/ } \\
\text { COUNTRY }\end{array}$ & DEFINITION \\
\hline \multicolumn{3}{|l|}{ University Affiliated } \\
\hline $\begin{array}{l}1 . \quad \text { Center for Civil Society } \\
\text { Studies http://ccss.jhu.edu/the- } \\
\text { center/about-the-center }\end{array}$ & $\begin{array}{l}\text { Johns Hopkins } \\
\text { USA }\end{array}$ & $\begin{array}{l}\text { 'We use the terms 'civil society sector' or } \\
\text { 'civil society organization' to refer to a } \\
\text { broad array of organisations that are } \\
\text { essentially private, i.e., outside the } \\
\text { institutional structures of government; that } \\
\text { are not primarily commercial and do not } \\
\text { exist primarily to distribute profits to their } \\
\text { directors or 'owners'; that are self- } \\
\text { governing; and that people are free to join or } \\
\text { support voluntarily. This definition was } \\
\text { formulated in collaboration with teams of } \\
\text { researchers and advisors from around the } \\
\text { world and has been used successfully to }\end{array}$ \\
\hline
\end{tabular}

\footnotetext{
${ }^{3}$ Note the table only covers centres that have 'civil society' this in their title and does not include a civil society focus eg Columbus State University’s Nonprofit and Civic Engagement Center (NPACE). There is also an array of scholarly societies that state that civil society is a key area of their focus including the US ARNOVA and the UK (ARVAC Association for Research in the Voluntary and Community Sector) and the International Society for the Third Sector Research (ISTR). David Horton Smith (2013, pp. 640-43) identifies around 30 similar interdisciplinary altruistics researcher associations and over 30 academic journals in his comprehensive review of the broad field of 'altruistics' ('all the related phenomena of our field, individual and collective. Included are philanthropy, the nonprofit sector, third sector, voluntary sector, civil society (sector), social economy, volunteering, associations, and nonprofit organizations, among other topics’). Note there has also been significant growth in the number of academic programs with a strong focus on civil society in particularly in the US programs with a focus on the nonprofit sector. In Australia, the nonprofit sector is now a significant area of academic research and learning, with nonprofit management education programs being offered in seven major Australian universities and two New Zealand tertiary education institutions (Malcolm, Onyx, Dalton \& Penetito 2014).
} 


\begin{tabular}{|c|c|c|}
\hline & & $\begin{array}{l}\text { guide field work in over } 40 \text { countries.' } \\
\text { This is contained in many of the } \\
\text { publications authored by Centre members } \\
\text { (ie by Lester Salamon; S. Wojciech } \\
\text { Sokolowski Regina List et al.) not on the } \\
\text { website directly. }\end{array}$ \\
\hline $\begin{array}{l}2 . \quad \text { Hauser Institute for Civil } \\
\text { Society } \\
\text { (The Hauser Center for Nonprofit } \\
\text { Organizations was established in } \\
1997 \text { in } 2013 \text { it merged with the } \\
\text { Center for Public Leadership at } \\
\text { the Harvard Kennedy School, and } \\
\text { became the Hauser Institute for } \\
\text { Civil Society) } \\
\text { http://hausercenter.org }\end{array}$ & $\begin{array}{l}\text { Harvard } \\
\text { University } \\
\text { Mas. USA }\end{array}$ & $\begin{array}{l}\text { The Hauser Institute for Civil Society at } \\
\text { Harvard University is a university-wide } \\
\text { center for the study of civil society and } \\
\text { nonprofit organisations. The Hauser Institute } \\
\text { seeks to expand understanding and } \\
\text { accelerate critical thinking about civil } \\
\text { society, its leaders and institutions among } \\
\text { scholars, practitioners, policy makers and } \\
\text { the general public by encouraging } \\
\text { scholarship, developing curriculum, } \\
\text { fostering mutual learning between } \\
\text { academics and practitioners, and shaping } \\
\text { policies that enhance the sector and its role } \\
\text { in society. }\end{array}$ \\
\hline $\begin{array}{l}\text { 3. The Centre for Civil } \\
\text { Society (founded in } 1995 \text { closed in } \\
\text { 2010) } \\
\text { http://www.spa.ucla.edu/civilsoci } \\
\text { ety/webfiles/template1.cfm?page= } \\
\text { abt_whtis.cfm\&mid=2 }\end{array}$ & LSE, UK & $\begin{array}{l}\text { 'Civil society refers to the arena of } \\
\text { uncoerced collective action around shared } \\
\text { interests, purposes and values. In theory, its } \\
\text { institutional forms are distinct from those of } \\
\text { the state, family and market, though in } \\
\text { practice, the boundaries between state, civil } \\
\text { society, family and market are often } \\
\text { complex, blurred and negotiated. Civil } \\
\text { society commonly embraces a diversity of } \\
\text { spaces, actors and institutional forms, } \\
\text { varying in their degree of formality, } \\
\text { autonomy and power. Civil societies are } \\
\text { often populated by organisations such as } \\
\text { registered charities, development non- } \\
\text { governmental organisations, community } \\
\text { groups, women's organisations, faith-based } \\
\text { organisations, professional associations, } \\
\text { trade unions, self-help groups, social } \\
\text { movements, business associations, } \\
\text { coalitions and advocacy groups.' } \\
\text { http://eprints.lse.ac.uk/29398/1/CCSReport0 } \\
5 \text { 06.pdf }\end{array}$ \\
\hline $\begin{array}{l}4 . \quad \text { The Centre for Civil } \\
\text { society } \\
\text { http://civilsociety.ucla.edu/ }\end{array}$ & $\begin{array}{l}\text { UCLA, Calif. } \\
\text { USA }\end{array}$ & $\begin{array}{l}\text { As above. Note common leadership / sister } \\
\text { relationship but also: 'civil society, adopted } \\
\text { an initial working definition that is meant to } \\
\text { guide research activities and teaching, but is } \\
\text { by no means to be interpreted as a rigid } \\
\text { statement:' } \\
\text { This is contained in many of the } \\
\text { publications authored by Centre members } \\
\text { but primarily developed by founder Helmut } \\
\text { Anheier (now Dean of the Hertie School of } \\
\text { Governance in Germany). }\end{array}$ \\
\hline International Council of & & Focuses on 'altruistics' ('all the related \\
\hline
\end{tabular}




\begin{tabular}{|c|c|c|}
\hline $\begin{array}{l}\text { Voluntarism, Civil Society, and } \\
\text { Social Economy Researcher } \\
\text { Associations (ICSERA; } \\
\text { www.icsera.org). } \\
\text { (est 2010) }\end{array}$ & & $\begin{array}{l}\text { phenomena of our field, individual and } \\
\text { collective. Included are philanthropy, the } \\
\text { nonprofit sector, third sector, voluntary } \\
\text { sector, civil society (sector), social } \\
\text { economy, volunteering, associations, and } \\
\text { nonprofit organizations, among other } \\
\text { topics'), David Horton Smith (2013) }\end{array}$ \\
\hline $\begin{array}{l}\text { 6. The Inglis Clark Centre for } \\
\text { Civil Society } \\
\text { http://www.utas.edu.au/provost/in } \\
\text { glis-clark-centre }\end{array}$ & UTAS & $\begin{array}{l}\text { Community engagement embeds and } \\
\text { extends the university as a key actor in civil } \\
\text { society - defined simply by the London } \\
\text { School of Economics as 'the arena of } \\
\text { uncoerced collective action around shared } \\
\text { interests, purposes and values'. } \\
\text { http://www.utas.edu.au/provost/inglis-clark- } \\
\text { centre }\end{array}$ \\
\hline $\begin{array}{l}7 . \quad \text { The Centre for Civil } \\
\text { society } \\
\text { http://www.ukzn.ac.za }\end{array}$ & $\begin{array}{l}\text { The University } \\
\text { of KwaZulu- } \\
\text { Natal (UKZN), } \\
\text { South Africa }\end{array}$ & $\begin{array}{l}\text { No definition but lists social movements, } \\
\text { trade unions, community-based } \\
\text { organisations and NGOs } \\
\text { http://www.ukzn.ac.za/civil } \\
\text { society/default.asp }\end{array}$ \\
\hline $\begin{array}{l}8 . \quad \text { The Centre for Civil } \\
\text { Society } \\
\text { Founded in } 1997 \text { by Parth Shah, } \\
\text { former Professor of Economics at } \\
\text { the University of Michigan. } \\
\text { http://www.civilsociety.in }\end{array}$ & New Delhi. India & $\begin{array}{l}\text { Civil society is an evolving network of } \\
\text { associations and institutions of family and } \\
\text { community, of production and trade, and of } \\
\text { piety and compassion. Individuals enter into } \\
\text { these relationships as much by consent as by } \\
\text { obligation but never under coercion. ...The } \\
\text { 'principle of subsidiarity' demarcates the } \\
\text { proper arenas for civil and political society, } \\
\text { and for local, state, and central government } \\
\text { within the political society. Civil society } \\
\text { champions individual rights, freedom of } \\
\text { exchange, rule of law and limited } \\
\text { government for India to reap the benefits of } \\
\text { political and economic freedom. } \\
\text { http://www.civil society.in/about_us.html }\end{array}$ \\
\hline $\begin{array}{l}9 . \quad \text { Cosmopolitan Civil } \\
\text { Society Research Centre (Est } \\
\text { 2007) } \\
\text { http://www.ccs.uts.edu.au }\end{array}$ & $\begin{array}{l}\text { UTS, NSW } \\
\text { Australia }\end{array}$ & $\begin{array}{l}\text { No definition but refers to multidisciplinary } \\
\text { perspectives to investigate 'the practices that } \\
\text { are crucial in enabling social cohesion and } \\
\text { change in cosmopolitan societies'. }\end{array}$ \\
\hline $\begin{array}{l}10 . \quad \text { The Civil Society } \\
\text { National Centre for Excellence } \\
\text { Consultation process began June } \\
\text { 2014, to go out to tender second } \\
\text { half } 2014 \\
\text { www.civilsocietycentre.org.au. * }\end{array}$ & Australia & $\begin{array}{l}\text { Definition changed from } \\
\text { Civil Society Organisations (CSOs) refers to } \\
\text { organisations with a primary focus on social } \\
\text { purpose* whether local, regional or national, } \\
\text { whether voluntary, not-for-profit or social } \\
\text { enterprise. } \\
\text { (added after first round of consultation) } \\
\text { 'Civil Society also incorporates relationships } \\
\text { and interactions between CSOs, people in } \\
\text { communities and organisations in different } \\
\text { sectors (including business and government) } \\
\text { working towards stronger social outcomes.' } \\
\text { *Social purpose may include (and is not } \\
\text { limited to) health, social services, education, } \\
\text { research, culture, arts, sport,recreation, }\end{array}$ \\
\hline
\end{tabular}




\begin{tabular}{|c|c|c|}
\hline & & $\begin{array}{l}\text { religion, community development, } \\
\text { employment \& training, housing, ageing, } \\
\text { disability, environment, lawand advocacy. } \\
\text { http://www.civilsocietycentre.org.au/wp- } \\
\text { content/uploads/2014/06/Civil-Society- } \\
\text { Discussion.pdf }\end{array}$ \\
\hline \multicolumn{3}{|l|}{ Community/government affiliated } \\
\hline $\begin{array}{l}11 . \quad \text { The Centre for Civil } \\
\text { Society } \\
\text { http://www.civilsociety.org.au/ }\end{array}$ & $\begin{array}{l}\text { (Social Enterprise } \\
\text { Partnerships Ltd) } \\
\text { Melbourne, } \\
\text { Australia }\end{array}$ & $\begin{array}{l}\text { The term 'civil society' refers to the } \\
\text { relationships and associations that make up } \\
\text { our life at grass-roots levels of society, } \\
\text { independent of government (in families, } \\
\text { neighbourhoods and voluntary } \\
\text { associations). } \\
\text { http://www.civilsociety.org.au/ }\end{array}$ \\
\hline $\begin{array}{l}12 . \quad \text { CIVICUS } \\
\text { (global nb.large Africa-based } \\
\text { membership) ' an international } \\
\text { alliance of members and partners.' } \\
\text { http://civicus.org/ }\end{array}$ & $\begin{array}{l}\text { Main office } \\
\text { Johannesburg, } \\
\text { South Africa also } \\
\text { offices in } \\
\text { Switzerland, US } \\
\text { \&UK. }\end{array}$ & $\begin{array}{l}\text { CIVICUS: World Alliance for Citizen } \\
\text { Participation is which constitutes an } \\
\text { influential network of organisations at the } \\
\text { local, national, regional and international } \\
\text { levels, and spans the spectrum of civil } \\
\text { society. CIVICUS includes the following } \\
\text { in its definition of civil society: civil } \\
\text { society networks and organisations; trade } \\
\text { unions; faith-based networks; professional } \\
\text { associations; NGO capacity development } \\
\text { organisations; philanthropic foundations } \\
\text { and other funding bodies } \\
\text { http://civicus.org/index.php/about-us-125 }\end{array}$ \\
\hline $\begin{array}{l}\text { 13. The Ghana Civil society } \\
\text { Resource Centre } \\
\text { http://civilsocietyghana.org }\end{array}$ & $\begin{array}{l}\text { UNDP \& } \\
\text { CIVICUS / Ghana }\end{array}$ & $\begin{array}{l}\text { No definition but refers to providing } \\
\text { 'services and support to Civil Society } \\
\text { Organisations engaged in civic education, } \\
\text { human rights, women's advocacy, and anti- } \\
\text { corruption } \\
\text { http://civilsocietyghana.org/index.php?opti } \\
\text { on=com_content\&task=view\&id=12\&Item } \\
\text { id=31 Note affiliation with UNDP - i.e. } \\
\text { government affiliation; Strong emphasis on } \\
\text { need to capacity build Southern NGOs to } \\
\text { meet conditions of Western funders (incl } \\
\text { UNDP) }\end{array}$ \\
\hline $\begin{array}{l}\text { 14. Centre for Studies of Civil } \\
\text { Society and Nonprofit Sector } \\
\text { http://www.grans.hse.ru/ }\end{array}$ & $\begin{array}{l}\text { National Research } \\
\text { University Higher } \\
\text { School of } \\
\text { Economics } \\
\text { Moscow, Russia }\end{array}$ & $\begin{array}{l}\text { Scientific studying of civil society and } \\
\text { nonprofit sector institutes is an important } \\
\text { line of research of the contemporary } \\
\text { Russian society because the said institutes } \\
\text { have become a signal of transformation } \\
\text { processes in our country. Specific research } \\
\text { trends both fundamental and applied, } \\
\text { focused on the range of civil society } \\
\text { problems, are forming in the context of } \\
\text { different sciences. (might have a definition } \\
\text { somewhere but rest of site is in Russian) }\end{array}$ \\
\hline $\begin{array}{l}\text { 15. Center for Strategic } \\
\text { Philanthropy and Civil Society }\end{array}$ & $\begin{array}{l}\text { Duke University, } \\
\text { US }\end{array}$ & $\begin{array}{l}\text { The Center for Strategic Philanthropy and } \\
\text { Civil Society (CSPCS) researches, } \\
\text { analyzes, and promotes philanthropy that } \\
\text { consistently produces high impact. CSPCS }\end{array}$ \\
\hline
\end{tabular}




\begin{tabular}{|c|c|c|}
\hline http://cspcs.sanford.duke.edu/ & & $\begin{array}{l}\text { stimulates communication, collaboration, } \\
\text { and problem-solving around pressing } \\
\text { issues of public policy and philanthropy. }\end{array}$ \\
\hline $\begin{array}{l}\text { 16. The Office for Civil } \\
\text { Society (2008-2011) } \\
\text { http://www.civilsociety.co.uk/dire } \\
\text { ctory/company/2765/office_for_ci } \\
\text { vil_society }\end{array}$ & $\begin{array}{l}\text { UK Government } \\
\text { (it replaced the } \\
\text { Office of the } \\
\text { Third Sector } \\
\text { following the } \\
\text { general election in } \\
2010 \text { but was } \\
\text { abolished in } \\
\text { 2011). }\end{array}$ & $\begin{array}{l}\text { Archived website does not show use of } \\
\text { definition but states that it 'holds } \\
\text { responsibility for charities, social } \\
\text { enterprises and voluntary organisations in } \\
\text { the Cabinet Office. } \\
\text { http://www.civilsociety.co.uk/directory/co } \\
\text { mpany/2765/office_for civil society }\end{array}$ \\
\hline
\end{tabular}

The definition of civil society posted on the websites of the Centres for Civil Society in UCLA and LSE (Numbers 3 and 4 above) were both at some point headed by Helmut Anheier and while in these positions used the same definition and also stressed flexibility in the definition: '[we] adopted an initial working definition that is meant to guide research activities and teaching, but is by no means to be interpreted as a rigid statement' (Center for Civil society UCLA, accessed November 2007).

Other groups, notably the Melbourne based Centre for Civil Society which not aligned with a university, see civil society from more of a self-help or 'capacity for collective organising' perspective (The Centre for Civil Society 2014). It appears for this group that the value of civil society lies in its capacity to stimulate collective effort to realise local benefit.

A number of the research centres for civil society (e.g. South Africa and CIVICUS) appear to not provide any definition civil society, at least on their website, but list various civic organisations and in particular nonprofit organisations or NGOs as the key unit of analysis. Also listed above is the UK cabinet-level Office for the Third Sector which was renamed the Office for Civil Society. (The conservative embrace of the term is an interesting development in the evolution of the term 'civil society' is discussed below).

At the time of writing, in Australia the centre-right Abbott Federal Government (2012 - ) is funding a research centre based at the University of NSW's, the Centre for Social Impact to conduct a consultation process to inform the design of a proposed Civil Society National Centre for Excellence (NCE), 'to enhance the institutions of civil society, including through collaboration, education, training, representation and advocacy for the sector' (CSI 2014). The Federal Coalition said that it is committed to abolishing 'the Australian Charities and 
Not-for-profit Commission and replace it with a smaller sector-focused Centre for Excellence.' However, given that many of ACNC regulatory functions would return to the Australian Taxation Office and the Australian Securities and Investments Commission reference to it being a 'replacement' has recently been dropped.

To date the consultation process around setting up the Centre for Excellence has involved the Centre for Social Impact conducting an online survey with 227 responses and several focus groups principally made up of those working in the nonprofit sector (CSI 2014). In the consultation process, the definition of civil society was hotly debated. The proposed definition that 'Civil society encompasses a wide range of organisations with a primary focus on social purpose, from the smallest community groups to large national organisations, whether voluntary, not-for-profit or social enterprise, as well as their interactions with local communities, business and government.' was questioned by some respondents:

This definition (and in particular as demonstrated by the diagram) will inevitably lead to governments/ agencies and for-profit businesses representing themselves, or being portrayed by others, as forming part of civil society, even though neither of these two sectors has a primary focus on social purpose. This dilution of what the 'civil sector' or 'third sector' means is a step backwards (Survey respondent) (CSI 2014, p.3.)

I think the definition of Civil Society Organisation is too narrowly defined - it should also include companies that use the power of business to solve social and environmental problems - see B Corp Certification (Survey respondent) (CSI 2014, p. 3)

Various respondents questioned why civil society was equated to organisations and not relationships: 'The definition should be the 'traditional' definition of civil society focused on relationships between individuals and social relationships in society' According to the report 'this (and similar views) is a very strongly held view in some stakeholders' (report's italics) (CSI 2014, p. 3).

CSI concludes that civil society language is not in as common usage in Australia as in some overseas countries; and that may be either a barrier or an opportunity to define or introduce it. 'Retaining this name - depending on the scope of the final NCE - will also alienate some. Inclusion or specific exclusion of relationships with either business or government sector is an important question in refining the scope of the NCE' (CSI 2014, p. 3). 


\section{Civil Society and Big Society: Aligning Civil Society with Neoliberal Agenda}

While having progressive connotations, the term has proved flexible enough to be a talismanic theme among political thinkers from both left and right. In recent times it has been adopted by conservative governments in the UK and Australia.

One of the most interesting contemporary advocates civil society is the English theologian and Director of the ResPublica think tank, Phillip Blond, whose 'Red Toryism' borrows from both the right's and the left's uses of civil society (Blond 2010). Blond's ideas have been a driving force behind the UK Conservative Cameron government's 'Big Society', in particular the government's commitment to a smaller state and an expanded role for the community sector (Cameron 2011). Like Red Toryism, Big Society argues that the British government has crowded out civil society organisations and undermined social capital and, to correct this, powers must be devolved from the central governments to local communities, small businesses, and volunteerism. The Cameron government embraced the term civil society and early in their first term, established the Office of Civil Society (number 17 in table above. Note it was closed in 2011) Senior Conservative party Member Nick Hurd was appointed the first Minister for Civil Society in May 2010 (he was replaced by Conservative MP Brooks Newmark in July 2014) (Meade 2014).

In Australia, similar sentiments in favour of smaller government have been expressed by the conservative Liberal Party, Tony Abbott referenced Big Society principles in a 'landmark' speech in 2012, saying that 'securing our future depends more on strong citizens than big government'(Abbott 2012), although the Australian Liberals seem to deliberately avoid any reference to the term "Big Society”. Like the UK's Cameron government, the Abbott Government has embraced the term civil society, often in reference to the not-for-profit sector, take for example the government commitment to establish a Civil Society National Centre for Excellence (NCE). The term ‘civil society' has been central to the Coalition's construction of the appropriate role for government and, by extension, its approach to the activities of the organisations within civil society, such as the funding and policy settings affecting community and not-for-profit organisations. In 2011, now Minister for Social Services Kevin Andrews evoked Edmund Burke’s 'little platoons', when he wrote, 'the essential task of civil society - families, neighbourhood life, and the web of religious, economic, educational, and civic associations - is to foster competence and character in 
individuals, build social trust, and help children become good people and good citizens' (Andrews 2011). According to a report titled Big Society and Australia by Australia’s Centre for Policy Development James Whelan, “elements of Cameron's agenda have been endorsed by the Centre for Civil Society, the Centre for Social Impact, the Sydney Institute and by the Institute of Public Affairs whose director, John Roskam, urged Tony Abbott to adopt the 'Big Society’ program (Whelan, 2012: 6; Roskam, 2010).

'Big Society' has been widely criticized as using progressive sounding jargon to present longstanding neoliberal preferences for shrinking government through budget cuts, privatisation and outsourcing (Davies and Pill, 2011). In terms of the use of civil society, cooption of the terms has been criticized for the way in which individuals are recast as entrepreneurs, and civil society becomes an amalgam of consumers and end-users having ‘choice’ (BBC 2010; The Times 14-Apr-2010). Still it is no doubt that the term progressive connotations of the term "civil society" has been a useful softening agent in the delivery of messages around budget cuts which are needed to end the "age of entitlement".

\section{What does this mean for the study of civil society?}

In 2003 the British Library made an attempt to sort through all the definitions of civil society. It concluded that 'All observers agree that civil society refers to voluntary participation by average citizens and thus does not include behavior imposed or even coerced by the state' (British Library 2004).

But as noted at the outset, there is currently no consensus on when civil society emerged and what it is understood to represent, that is, who and what it is seen to include - who inhabits it, where the conceptual boundaries lie and which version of civil society should prevail? Should we include business or the 'market'? By extension, should we include economic associations such as trade groups, professional organisations and labor unions? What about political organisations? Should we distinguish between political organisations and politically aligned or motivated groups? What about the family and even illegal bodies such as cartels and crime rings? In many examples of definitions it is not what a particular approach includes that is as significant as what is effectively excluded and why.

One can be pessimistic or optimistic about the consequences of this definitional confusion. 


\section{Being Pessimistic}

It can be argued that civil society definitional imprecision can undermine current relevance and usefulness, indeed it can threaten to cut civil society loose from any meaning at all. According to Chandhoke (2003, p. 13), 'civil society today has been reduced to a onedimensional, watered down concept that has ceased to have any definite meaning'. Some scholars have warned that the term will soon fall into disuse unless some agreement can be arrived at. Brian O’Connell writes that 'We will/are left with no basis for future research work...Any hope of achieving awareness of civil society depends on our ability to make it strikingly visible and manifestly consequential. That begins with a solid understanding of just what civil society is and does' (O’Connell 2000, p. 471).

On the bright side...

Let many flowers bloom! It could be argued that civil society is simply suffering the same limitations as its inhabitants, eg- diverse, prone to contestation and debate, critical, dynamic, heterogeneous. I believe, like the British Library, civil society has excavated some common ground.

\section{The Centre for Cosmopolitan civil society at UTS: A meeting place for overlapping} frames

The social sciences collectively know too little to waste time on foolish disciplinary squabbles. Disciplinary disputes and turf wars are of little or no importance. In my mind, this book is as much a work of history as of economics. Thomas Piketty 2014 p. 37.

Established at the University of Technology, Sydney, in 2007, the Cosmopolitan Civil Societies Research Centre is a cross-faculty, cross-disciplinary centre committed to community engaged academic research that investigates the broad field of Cosmopolitanisms and Civil Societies (CCS 2012).

CCS grew from academics across two faculties, Arts and Social Science and Business, who engaged in interdisciplinary research but now welcomes members from across UTS. After extended deliberations it was decided to incorporate the term cosmopolitan in the centre's title. Cosmopolitan is used to describe the leadership of civil society in the international arena contribution of Diaspora communities to Australian society. It was chosen because it decouples the analysis of leadership from nations or territories, and focuses more on civil society's leaders' mindsets instead of on the physical reach of their organisations. It was also 
a deliberate choice to help reclaim the positive meaning of a word that has a long and distinguished history, but also a controversial one that serves to illustrate of potential perils of the use of any one term. ${ }^{4}$ In the last decades, however, cosmopolitan has been reclaimed by civil society founders and others as a descriptor for those who value diversity and are at ease working with different cultures and countries - a global cosmopolitanism that brings human rights and social justice into its primary operational frame. Civil society is thus studied with the view to identifying the practices that are crucial in enabling social cohesion and change in cosmopolitan societies.

In recognition of how research on civil society is becoming increasingly diverse and scattered across multiple disciplines, CCS researchers share an interest in investigating civil society from multi-disciplinary perspectives. To do so they incorporate the theories and methodologies developed by historians, sociologists, and political scientists, management researchers and economists. Within this interdisciplinary field members engage a range of theoretical approaches to cosmopolitanism and to civil society, articulate differing analytical concepts, and build multidisciplinary on-the-ground investigations. The research program centres around nine thematic areas: Alternative Cosmopolitanisms; Cultural Life and Events; Indigeneity and Power; Migration, Diversity \& Racism; Human Rights, Inclusion and Communication; Collective Action and Learning; Strengthening Civil Societies; Knowledgesharing and Information in Civil Society; Sport and Social Action and Environment \& Society.

In many ways, the CCS membership represents in microcosm the contested field of civil society with advocates of many and sometimes opposing versions of civil society that have been highlighted in this paper. To some extent they may be guilty of demonstrating tendency to preference one part of civil society and focus on a particular setting and then equate the phenomena that they observe to civil society itself. Some members have focused their civil society research on the transformative power of social movement organisations, while others view civil society principally through the lens of nonprofit organisations under the descriptor of 'third sector'. Others decry the uncritical transfer the concept of civil society to non-

\footnotetext{
${ }^{4}$ During much of the $20^{\text {th }}$ Century, particularly in the Nazi and Communist eras in Europe and the Soviet Union, cosmopolitan was often a pejorative epithet used for those deemed disloyal to a nation or regime and beholden to foreign elements because of their ethnicity, religion, ideology or worldview. Members of the opposition were branded 'cosmopolitan traitors' and the term was often used by anti-Semitic elements as a code word for 'Jewish'.
} 
western and Indigenous settings. Perhaps the difference is that these members exchange views in what is, for the most part, an open, discursive and democratic space, in efforts to forge common ground and boost interdisciplinary collaborations. The range of ideas and the arguably previously unlikely coupling of scholars across diverse fields in co-authored research that has appeared in the last five years of the Cosmopolitan Civil Societies: An Interdisciplinary Journal is testimony to, at the least, a capacity to get along and, at best, the excavation of some common ground.

Do these experiments of collaboration among the members of CCS, and among members of the various centres for civil society discussed above, suggest that in due course interdisciplinary collaborations will precipitate some decisions regarding defining civil society being made? Or are attempts to pin down a dynamic, contested and evolving term with a long and rich scholarly history simply a fool's quest? Such an endeavour may even miss the main point, that interdisciplinary collaboration continues to add to conceptual dimensions of approaches to the study of civil society that can shed light into previously unknown corners. It can also show us not what civil society is or is not but how go about conducting civil society research.

\section{Conclusion}

So after this long lament over the absence of consensus regarding a definition - and thus the debate's tendency toward generating heat not light - I, hypocritically, also avoid the task. Maybe as Helmut Anheier says we have 'become very conceptual and overly focused on the issue of definitions relative to empirical research findings. And instead we need to evaluate the empirical approach itself, and in particular its level of contribution to the study of global civil society thus far' (2007, p. 1).

Perhaps the real question should not be what it 'civil society' but 'how does it matter' Ongoing questioning of definitions is routinely applied to virtually all social science concepts of any note, with the usual conclusion that if we can't define it, the concept and therefore the content of that concept will disappear or become meaningless. But conceptual definitions are always fluid because: a) the world we are concerned with changes and b) inevitably any concept that connotes progressive thinking of 'the left' is co-opted and transformed by the political right for its own purposes. So perhaps the critical challenge for any new research centres claiming to have civil society as a core focus is to think carefully and constructively 
about how they wish to study civil society. Interdisciplinary approaches are critical to meeting this challenge.

\section{References}

Abbott. T., 2012 Address to the Victorian Employers Chamber of Commerce Mar 9, 2012 http://www.liberal.org.au/latest-news/2012/03/09/address-victorian-employers-chambercommerce-and-industry-0

Almond, G. \&Verba, S. 1989, The Civic Culture: Political Attitudes and Democracy in Five Nations, Sage Publications, London.

Anheier, H. 2004, Civil Society: Measurement, Evaluation, Policy, Earthscan, London.

Anheier, H. 2007, 'Reflections on the concept and measurement of global civil society', Voluntas, vol. 18, no.1, pp. 1-14. doi: http://dx.doi.org/10.1007/s11266-007-9031-y

Andrews, K. 2011, ‘Empowering civil society’, Australian Polity, vol. 3 no.2, http://australianpolity.com/feature/empowering-civil-society

Barber, B. 1996, 'Strengthening democracy by recreating civil society', Paper presented at the Independent Sector Conference on Civil society, 5 September, Washington, DC.

Billante, N. \& Saunders, P. 2002, 'Why civility matters', Policy, vol. 18, no. 3, pp. 32-36. http://www.cis.org.au/POLICY/Spring02/polspring02-6.pdf

Blond, P. 2010, Red Tory Red Tory: How Left and Right Have Broken Britain and How We Can Fix It, Faber, London.

British Library 2003, 'Civil society’ - An Agreed Definition http://pages.britishlibrary.net/blwww3/3way/civilsoc.htm; (No longer available as of April $28^{\text {th }}$ 2013).

Butcher, J., Casey, J. \& Dalton, B. 2012, ‘An Australian National Compact - Something old, something new?', Nonprofit Policy Forum, vol. 3, no.2. doi: http://dx.doi.org/10.1515/2154$\underline{3348.1038}$

Calhoun, C. 2000, 'The virtue of civility’,Philosophy and Public Affairs, vol. 29, no. 3, pp. 255. doi: http://dx.doi.org/10.1111/j.1088-4963.2000.00251.x

Carothers, T., Barndt, W. \& Al-Sayyid, M. 1999/2000, 'Civil society’, Foreign Policy, Winter, pp. 18-29. doi: http://dx.doi.org/10.2307/1149558

Center for Civil society (year unknown) What is civil society? University of California, Los Angeles, URL:

http://www.spa.ucla.edu/ccivilsociety/webfiles/template1.cfm?page=abt_whtis.cfm\&mid=2 accessed July 2010.

Centre for Social Impact, University of New South Wales (CSI) 2014, Mid Project Report: Draft Models for Consultation for the establishment of a Civil Society National Centre for Excellence. July 21, 2014 http://www.civilsocietycentre.org.au/about-the-project/draft-models/

Chandhoke, N. 2002, 'The limits of global civil society' in Glasius, M. Kaldor, M. and Anheier, H. (eds) Global Civil society, Oxford University Press, Oxford, pp. 35-53.

Chandhoke, N. 2003, The Conceits of Civil Society, Oxford University Press, New Delhi.

Chandhoke, N. 2005, 'What the hell is civil society?', Open Democracy, 17 March. http://www.opendemocracy.net/democracy-open_politicivil society/article 2375.jsp.

Chatterjee, Partha 2001, 'On civil and political society in postcolonial democracies,' in Kaviraj, S. and Khilnani, S. (eds), Civil Society: History and Possibilities, Cambridge University Press, Cambridge, pp. 165-178. 
Chatterjee, Partha 2006, The Politics of the Governed: Reflections on Popular Politics in Most of the World (Leonard Hastings Schoff Lectures) Columbia University, New York.

Cohen, J. 1995, 'Interpreting the notion of civil society' in Walzer, M. (ed.), Toward a Global Civil Society, Berghahn Books, Oxford, pp. 35-40.

Comaroff, J.\& Comaroff, J. (eds.) 2001, Millennial Capitalism and the Culture of Neoliberalism, Duke University Press, Durham, North Carolina. doi: http://dx.doi.org/10.1215/9780822380184

Cotton, J. 2002, 'Civil society in the political transition of North Korea: the limitations of the East European model', Korea and World Affairs, vol. 16, no.2, pp. 319-337.

Cummings, B. 2002, 'Civil society in West and East' in Armstrong, C. (ed.), Korean Society: Civil Society, Democracy, and the State, Routledge, New York.

Dalton, B. and Butcher, J. 2014, 'Australian civil society and the C20: now isn't the time to be polite', The Conversation 18 June 2014 https://theconversation.com/australian-civil-society-and-thec20-now-isnt-the-time-to-be-polite-27863).

Davies, J.S. \& Pill, M. 2011, 'Empowerment or abandonment? Prospects for neighbourhood revitalization under the Big Society', Public Money and Management, vol. 32, no. 3, pp.193200. doi: http://dx.doi.org/10.1080/09540962.2012.676276

de Tocqueville, A. 1835 - 1840/2000, Democracy in America English language versions: Tocqueville, Democracy in America, trans. and eds., Mansfield, H. and Winthrop, D. University of Chicago Press.

Diamond, L. 1994, 'Rethinking civil society: Toward democratic consolidation', Journal of Democracy, vol. 5, no. 3, pp. 4-17. doi: http://dx.doi.org/10.1353/jod.1994.0041

Diamond, L. 1997, 'Consolidating Democracy in the Americas', The Annals of the American Academy of Political and Social Science, vol. 550, no. 1, pp. 12 - 41. doi: http://dx.doi.org/10.1177/0002716297550001002

Edwards, M. 2004, Civil Society, Polity Press, London.

Emery, P., 2012 “'Big Society” and civil society’, The Guardian [retrieved 2 September 2014] http://www.theguardian.com/voluntary-sector-network-zurich-partner-zone/big-society-andcivil-society

Ewin, R. 1991, Virtues and Rights; The Moral Philosophy of Thomas Hobbes, Westview Press, Boulder.

Foley, M. \& Edwards, B. 1996, 'The paradox of civil society', Journal of Democracy, vol. 7, no. 3, pp. 38-52. doi: http://dx.doi.org/10.1353/jod.1996.0048

Graham, G. 1997, Ethics and International Relations, Blackwell, Oxford.

Gellner, E. 1990, The Civil and the Sacred, in XII The Tanner Lectures on Human Values 301, 303 (delivered at Harvard University, 20-21 Mar. 1990).

Hall, J. ed. 1995, Civil Society: Theory, History, and Comparison, Polity Press, Cambridge.

Hampton, J. 1986, Hobbes and the Social Contract Tradition, Cambridge University Press, Cambridge.

Harbeson, J.W. 1994, 'Civil society and political renaissance in Africa', in Harbeson, J.W.,. Rothchild, D and Chazan, N. (eds.), Civil Society and the State in Africa, Lynne Reinner, Boulder, Colorado.

Hauss, C. 2003, 'Civil Society’ in Burgess, G. and Burgess, H. (eds.) Beyond Intractability, Conflict Information Consortium, University of Colorado, Boulder. Posted: August 2003 $<$ http://www.beyondintractability.org/essay/civil-society>.

Hegel, G. F. W. 1991, Philosophy of Right, Wood, A. (ed.), Cambridge University Press, Cambridge. Horton Smith, D. 2013, 'Global growth of the organized, interdisciplinary, research field of altruistics (nonprofit and voluntary sector studies)' http://www.vssn.org.uk/vssnmedia/dcdocs/2013MayHortonSmith.pdf 
Huntington, S. 1991, The Third Wave Democratization in the Late Twentieth Century, University of Oklahoma Press, Norman.

Keane, J. (ed) 1988, Civil society and the State: New European Perspectives, Verso Books, London. Keane, J. 1998, Civil Society: Old Images, New Visions, Stanford University Press, Stanford.

Kaviraj, S. 2001, 'In search of civil society', in Kaviraj, S. and Khilnani, S. (eds.). Civil Society: Histories and Possibilities, Cambridge University Press, Cambridge.

Kelsay, J. 2002, 'Civil Society and Government in Islam' in Hashmi, S. (ed.) Islamic Political Ethics: Civil Society, Pluralism, and Conflict, Princeton University Press, Princeton, NJ.

Kuper, A. and J. Kuper (eds) 1985, The Social Science Encyclopedia, London: Routledge \& Kegan Paul, pp. 355-6.

Leonard, M. 2004, 'Bonding and bridging social capital: Reflections from Belfast', Sociology, vol. 38, no. 5, pp. 927-944. doi: http://dx.doi.org/10.1177/0038038504047176

Leonard, R. \& Onyx, J. 2003, 'Networking through loose and strong ties: an Australian qualitative study', Voluntas, vol. 14, no. 2, pp. 189-203. doi: http://dx.doi.org/10.1023/A:1023900111271

Lewis, D. 2001, Civil society in non-Western contexts: reflections on the 'usefulness' of a concept, Civil Society Working Paper series, 13. eprints.lse.ac.uk/29052/

Lipset, S.M. 1956, Union Democracy, Anchor Books, Garden City.

Lipset, S.M. 1967, 'Values, education, and entrepreneurship', in Lipset, S. and Solari, A. (eds.), Elites in Latin America, Oxford University Press, London.

Locke, J. 1965, 'Treatise of civil government and a letter concerning toleration', Irvington, New York.

Malcolm, M., Onyx, J., Dalton, B., \& Penetito, K. (in press, 2014), 'Not-for-profit management education down under: Challenges and opportunities', Journal of Nonprofit Education and Leadership.

Meade, A. 2014 "Nick Hurd resigns: what do charities want from next civil society minister?” Guardian Professional, Tuesday 15 July 2014 http://www.theguardian.com/voluntary-sectornetwork/2014/jul/15/nick-hurd-resigns-what-do-charities-want-from-next-civil-society-minister.

Morris, R. J. 2006, 'Introduction: civil society, associations and urban places : class, nation and culture in nineteenth-century Europe', in de Vries, B., Morris R. and Morton, G. (eds.), Civil Society, Associations and Urban Places: Class, Nation and Culture in Nineteenth-Century Europe, Ashgate, Aldershot.

Munck, R. 2006, 'Global civil society: Royal road or slippery path?', Voluntas, vol. 17, no. 4, pp. 325-332. doi: http://dx.doi.org/10.1007/s11266-006-9019-z

Nonprofit Academic Centers Council (NACC) 2014, Members list accessed 27 April 2014 at: http://www.nonprofit-academic-centers-council.org/.

Nietzsche, F. 1968, On the Genealogy of Morals tr. Kaufmann, W. and Hollingdale, R. in Basic Writings of Nietzsche, Kaufmann, W. (ed.), Modern Library, New York.

O’Connell, B. 2000, ‘Civil Society: Definitions and Descriptions' Nonprofit and Voluntary Sector Quarterly, vol. 29 no. 3, pp. 471-478. doi: http://dx.doi.org/10.1177/0899764000293007

O’Donnell, G. \& Schmitter, P. 1986, Transitions from Authoritarian Rule: Tentative Conclusions about Uncertain Democracies, The Johns Hopkins University Press, Baltimore.

Onyx, J. \& Edwards, M. 2010, 'Community networks and the nature of emergence in civil society', Cosmopolitan Civil Societies: An Interdisciplinary Journal, vol. 2, no. 1, pp. 1-20.

Piketty, T. 2014, Capital in the 21 Century, Harvard University Press.

Pitts, J. 2009, A turn to empire: The rise of imperial liberalism in Britain and France, Princeton University Press.

Portes, A. 1998, 'Social capital: Its origins and applications in modern sociology', Annual Review of Sociology, vol. 22, pp. 1-24. doi: http://dx.doi.org/10.1146/annurev.soc.24.1.1 
Putnam, R. 1993, Making Democracy Work: Civic Traditions in Modern Italy, Princeton University Press, Princeton.

Putnam, R. 1995, 'Bowling alone: America's declining social capital', Journal of Democracy, vol. 6, no. 1, pp. 65-78. doi: http://dx.doi.org/10.1353/jod.1995.0002

Putnam, R. 1996, 'The strange disappearance of Civic America', The American Prospect, no. 24.

Pye, L.W. 1999, 'Civility, social capital, and civil society: Three powerful concepts for explaining Asia’, Journal of Interdisciplinary History, vol. 29, no. 4, pp. 763-782. doi: http://dx.doi.org/10.1162/002219599551886

Roskam, J., 17/9/10, 'Abbott needs a to-do list', Institute of Public Affairs [retrieved 10 October 2011] http://ipa.org.au/sectors/governance-service-provision/news/2206/abbottneeds-a-to-do-list/pg/8

Salamon. L . \& Anheier, H. 1997, ‘The civil society sector’, Society, vol.34, no.4, pp. 60-65. doi: http://dx.doi.org/10.1007/BF02823101

Schmitter, P. 1995, 'On civil society and the consolidation of democracy: Ten propositions’, mimeograph, Stanford Department of Political Science.

Schwartz, F. J. 2003, 'Introduction: Recognizing civil society in Japan', in Schwartz, F. and Pharr, S. (eds.), The State of Civil Society in Japan, Cambridge University Press, Cambridge. doi: http://dx.doi.org/10.1017/CBO9780511550195.002, http://dx.doi.org/10.1017/CBO9780511550195

Sen, J. 2010, Engaging Critically with the Reality and Concept of Civil Society, http://p2pfoundation.net/Engaging_Critically_with_the_Reality_and_Concept_of_Civil_Societ y Accessed April 2nd, 2014

Shils, E. 1997, 'Civility and civil society: Good manners between persons and concern for the common good in public affairs’, in Shils E. and Grosby, S. (ed.), The Virtue of Civility: Selected Essays on Liberalism, Tradition and Civil society, Liberty Fund, Indianapolis.

Skopol, T. 2003, Diminished Democracy: From Membership to Management in American Civil Life, University of Oklahoma Press, Norman.

Strauss, L. \& Cropsey, J. (eds.) 1987, History of Political Philosophy, University of Chicago Press, Chicago. doi: http://dx.doi.org/10.7208/chicago/9780226924717.001.0001

Verba, S., Schlozman K. \& Brady, H. 1995, Voice and Equality: Civic Voluntarism in American Politics, Harvard University Press, Cambridge.

Waltzer. M. 2002, 'Chapter 2: Equality and civil society’ in Chambers, S. and Kymlicka, W. (eds.), Alternative Conceptions of Civil Society, Princeton University Press, Princeton.

Warren, M. 2001, Democracy and Association, Princeton University Press, Princeton.

Whelan, J. 2012, "Big Society and Australia". Centre for Policy Development. http://cpd.org.au/wpcontent/uploads/2012/05/cpd_big_society-FINAL-WEB-VERSION.pdf

Whitehead, L. 1997, 'Bowling in the Bronx: The uncivil interstices between civil and political society’, in Fine, R. and Rai, S. (eds.) Civil Society: Democratic Perspectives, Frank Cass \& Co., London.

Wickramasinghe, N. 2005, 'The idea of civil society in the South: Imaginings, transplants, designs', Science \& Society, vol. 69, no. 3, pp. 458-486. doi: http://dx.doi.org/10.1521/siso.69.3.458.66521

The World Health Organisation website http://www.who.int/trade/glossary/story006/en/ Accessed 5 June 2014.

World Economic Forum 2013, 'The Future Role of Civil Society', World Economic Forum, http://www3.weforum.org/docs/WEF FutureRoleCivilSociety Report 2013.pdf

United Nations 2003, The United Nations: Partners in Civil Society. 
United Nations 1998, Secretary General Describes Emerging Era in Global Affairs with Growing Role for Civil Society Alongside Established Institutions, Press Release SG/SM/6638, 14 July 1998. Available at: http://www.un.org/News/Press/docs/1998/19980714.sgsm6638.html 